\title{
Recent Trends in Neuro-endovascular Treatment for Acute Ischemic Stroke, Cerebral Aneurysms, Carotid Stenosis, and Brain Arteriovenous Malformations
}

\author{
Yuji MATSUMARU, ${ }^{1}$ Eiichi IsHIKAWA, ${ }^{2}$ Tetsuya YAMAMOTO, ${ }^{2}$ \\ and Akira MATSUMURA ${ }^{2}$ \\ ${ }^{1}$ Division for Stroke, Department of Neurosurgery, Faculty of Medicine, \\ University of Tsukuba, Tsukuba, Ibaraki, Japan; \\ ${ }^{2}$ Department of Neurosurgery, Faculty of Medicine, University of Tsukuba, \\ Tsukuba, Ibaraki, Japan
}

\begin{abstract}
The efficacy of mechanical thrombectomy with stent retrievers for emergent large vessel occlusion has been proved by randomized trials. Mechanical thrombectomy is increasingly being adopted in Japan since stent retrievers were first approved in 2014. An urgent clinical task is to offer structured systems of care to provide this treatment in a timely fashion to all patients with emergent large vessel occlusion. Treatment with flow-diverting stents is currently a preferred treatment option worldwide for large and giant unruptured aneurysms. Initial studies reported high rates of complete aneurysm occlusion, even in large and giant aneurysms, without delayed aneurysmal recanalization and/or growth. The Pipeline Embolic Device is a flow diverter recently approved in Japan for the treatment of large and giant wide-neck unruptured aneurysms in the internal carotid artery, from the petrous to superior hypophyseal segments. Carotid artery stenting is the preferred treatment approach for carotid stenosis in Japan, whereas it remains an alternative for carotid endarterectomy in Europe and the United States. Carotid artery stenting with embolic protection and plaque imaging is effective in achieving favorable outcomes. The design and conclusions of a randomized trial of unruptured brain arteriovenous malformations (ARUBA) trial, which compared medical management alone and medical management with interventional therapy in patients with an unruptured arteriovenous brain malformation, are controversial. However, the annual bleeding rate $(2.2 \%)$ of the medical management group obtained from this study is worthy of consideration when deciding treatment strategy.
\end{abstract}

Key words: endovascular therapy, acute thrombectomy, cerebral aneurysm, carotid artery stenting, brain arteriovenous malformation

\section{Introduction}

Endovascular treatment for vascular diseases of the brain and spinal cord has gradually developed as a less invasive treatment and is now widely applied worldwide. Advances have been achieved through the development of device and imaging technology alongside an increased understanding of disease pathophysiology. Evidence obtained from milestone randomized controlled trials comparing conventional treatment and endovascular treatment has changed treatment strategies. ${ }^{1-7)}$ Breakthroughs in neuro-endovascular treatment for acute ischemic stroke have occurred in recent years, ${ }^{8-12)}$ accompanied by reliable progress in treating other diseases. This study examines recent trends and advancements in neuro-endovascular therapy.

Received February 2, 2017; Accepted February 14, 2017

\section{Acute thrombectomy}

Endovascular therapy for emergent large vessel occlusion began with intra-arterial fibrinolytic therapy in the 1980s. ${ }^{13)}$ However, despite refinement and sophistication of newly developed devices and imaging technology, its efficacy remained unproven. In 2015, the results of five randomized trials (medical therapy alone versus medical therapy with endovascular therapy), MR CLEAN ${ }^{8)}$ ESCAPE, ${ }^{9)}$ EXTEND-IA, ${ }^{10)}$ SWIFT PRIME, ${ }^{11)}$ and REVASCAT ${ }^{12)}$ were published, all of which demonstrated the positive effect of endovascular therapy for patients with emergent large vessel occlusion.

As a consequence of these trials, the European Stroke Organization (ESO) in collaboration with the European Society for Minimally Invasive Neurological Therapy (ESMINT) and the European Society of Neuroradiology (ESNR) released their consensus statement on 
mechanical thrombectomy in acute ischemic stroke (http://www.esmint.eu/sites/default/files/Consensus_ thrombectomy_ESO_Karolinska_ESMINT_ESNR_final. pdf). The Standards and Guidelines Committee of the Society of NeuroInterventional Surgery (SNIS) published their guideline "Embolectomy for stroke with emergent large vessel occlusion". ${ }^{14)}$ In 2015 the American Heart Association/American College of Cardiology (AHA/ASA) also published a focused update of the 2013 guidelines for the early management of patients with acute ischemic stroke regarding endovascular treatment. ${ }^{15)}$ AHA/ASA recommends endovascular therapy with a stent retriever for patients who meet all of the following criteria (Class I; Level of Evidence A): (a) pre-stroke modified Rankin Scale (mRS) score $0-1$; (b) acute ischemic stroke receiving intravenous recombinant tissue plasminogen activator within 4.5 $\mathrm{h}$ of onset according to guidelines from professional medical societies; (c) causative occlusion of the internal carotid artery (ICA) or proximal middle cerebral artery (M1); (d) age $\geq 18$ years; (e) National Institute of Health Stroke Scale (NIHSS) score of $\geq 6$; (f) Alberta Stroke Program Early Computed Tomography Score (ASPECTS) of $\geq 6$; and (g) treatment initiated (groin puncture) within $6 \mathrm{~h}$ of symptom onset. The Japan Stroke Society, the Japan Neurosurgical Society, and the Japanese Society of Neuroendovascular Therapy also produced their Guideline for proper usage of percutaneous transluminal thrombectomy devices, which was published in Japanese (Jpn J Stroke 37: 259-279, 2015).

Goyal et al. designed the Highly Effective Reperfusion evaluated in Multiple Endovascular Stroke Trials (HERMES) collaboration for the meta-analysis of individual patient data from five trials (MR CLEAN, ESCAPE, REVASCAT, SWIFT PRIME, and EXTEND IA) including 1287 patients (634 assigned to endovascular thrombectomy, 653 assigned to medical therapy. ${ }^{16)}$ Endovascular thrombectomy led to significantly reduced disability at 90 days compared with control (adjusted common odds ratio [OR] 2.49, 95\% confidence interval [CI] 1.76-3.53; $P<0.0001$ ). The number needed to treat with endovascular thrombectomy to reduce disability by at least one level on mRS for one patient was 2.6, which means that thrombectomy is a highly effective treatment compared with other treatments for stroke. ${ }^{17)}$ Campbell et al. also pooled 787 patients (401 randomized to endovascular thrombectomy and 386 to standard care) from trials in which the Solitaire (Medtronic, Irvine, CA, USA) (Fig. 1) was the only or the predominant device (SWIFT PRIME, ESCAPE, EXTEND-IA, and REVASCAT) (SEER Collaboration). ${ }^{18)}$ The common OR for mRS improvement was 2.7 (2.0-3.5). The number needed to treat to reduce disability was 2.5 , and successful revascularization occurred in $77 \%$ treated with the Solitaire device. The onsetto-TICI (Thrombolysis In Cerebral Infarction) 2b/3 time was a significant predictor of outcome (OR 0.99 per minute; $P=0.011$ ) with the probability of independent functional outcome declining $1 \%$ per 23-min delay. From the subanalysis of MR CLEAN, for every hour of reperfusion delay the initially large benefit of thrombectomy decreased the absolute risk difference for a good outcome by $6 \%$ per hour of delay, and the treatment effect was not significant beyond $6 \mathrm{~h} 18 \mathrm{~min}$ from onset. ${ }^{19)}$ Subanalysis of ESCAPE showed that every 30-min increase in computed tomography (CT)-to-reperfusion time reduced the probability of achieving a functionally independent outcome (90-day mRS $0-2$ ) by $8.3 \%$ $(P=0.006){ }^{20)}$ Subanalysis of REVASCAT also showed that longer onset to recanalization time was associated with a reduced likelihood of a good outcome (OR for 30-min delay 0.74; 95\% CI 0.59-0.93). ${ }^{21)}$ The influence of treatment delay on the treatment effect was remarkable.

Endovascular thrombectomy is now the standard treatment for patients with acute ischemic stroke caused by occlusion of the proximal anterior circulation with class I evidence. Therefore, we should provide this treatment for all patients who suffer acute ischemic stroke on transport to hospital or transfer the patient to a hospital providing this treatment as soon as possible. Our aim should be to offer structured systems of care to provide this treatment in a timely fashion to all patients with acute ischemic stroke caused by large vessel occlusion.

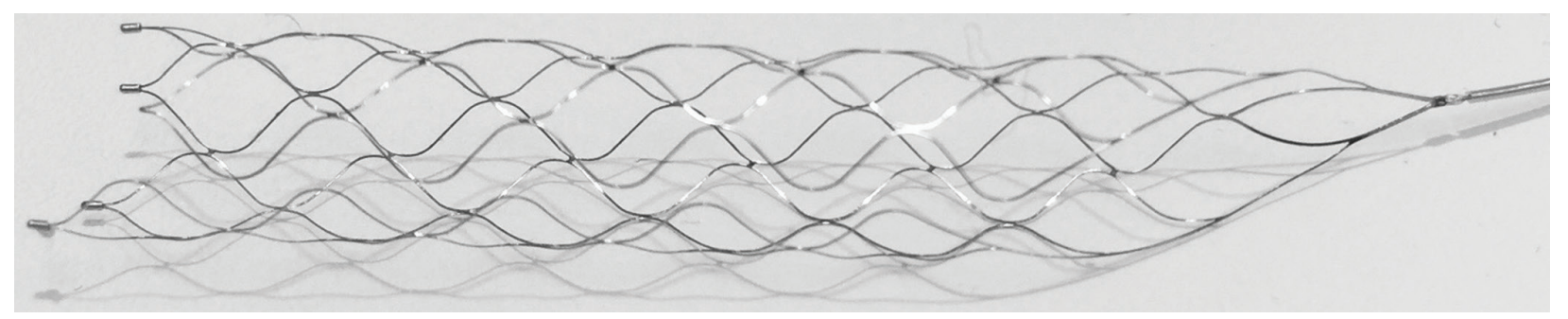

Fig. 1 Solitaire FR (Medtronic, Irvine, CA, USA). Stent-like retriever for acute thrombectomy. 


\section{Endovascular therapy with flow diverter for intracranial aneurysm}

A flow diverter (FD) is a stent-like device with more metal coverage and less porosity than neck-bridge stents for aneurysmal coiling. An FD disrupts the intra-aneurysmal flow, thus favoring intra-aneurysmal thrombosis and neointimal remodeling. The Pipeline Embolic Device (PED; Medtronic, Irvine, CA, USA) (Fig. 2) is the first FD for the treatment of cerebral aneurysms. ${ }^{22}$ The device consists of a braided mesh cylinder composed of 48 microfilaments. Initial studies reported high rates of complete aneurysm occlusion, even in large and giant aneurysms, without delayed aneurysmal recanalization and/or growth. ${ }^{22-26)}$ The PED received the CE mark of approval in 2008, followed by the US Food and Drug Administration approval in 2011. In Japan, the PED was approved in 2015 for the treatment of large and giant wideneck unruptured aneurysms in the ICA, from the petrous to superior hypophyseal segments. The Japan Neurosurgical Society, the Japan Stroke Society, and the Japanese Society of Neuroendovascular Therapy formulated the Guideline for the proper usage of flow-diverter stent (http://www.jsnet.umin.jp/sozai/ info-shonin/150403FD_shishin.pdf). The PED is now increasingly being used in 23 institutions across Japan in accordance with this guideline.

Kallmes et al. reported results of an international retrospective study of the PED registry including 793 patients with 906 aneurysms. ${ }^{27)}$ The neurological morbidity and mortality rate was $8.4 \%$, the highest being in the posterior circulation group $(16.4 \%)$ and the lowest in the group with ICA $<10 \mathrm{~mm}(4.8 \%)$ $(P<0.01)$. Use of the PED for posterior circulation aneurysms is considered higher risk and is beyond approved indication in Japan. The rate of spontaneous rupture and intracranial hemorrhage were reported as $0.6 \%$ and $2.4 \%$, respectively. The cause of these hemorrhagic complications is yet to be completely elucidated. ${ }^{28)}$
The PED for ICA aneurysms usually covers some branches such as the ophthalmic artery and anterior choroidal artery (AChA). Patients treated with the PED for large and giant ICA aneurysms had excellent neuro-ophthalmological outcomes 6 months after the procedure in the PUFS trial, ${ }^{25)}$ with deficits improving in most of the patients (64\%), very few deficits worsening $(2.6 \%)$, and few new deficits developing (5\%). ${ }^{29)}$ Neki et al. retrospectively analyzed 20 consecutive patients with unavoidable covering of the AChA with a single PED. ${ }^{30}$ No patient complained of transient or permanent symptoms related to an AChA occlusion. In all cases, the AChA remained patent without any flow changes during follow-up.

Treatment with an FD is currently the preferred option for large and giant unruptured aneurysms in the ICA. However, delayed ischemic complications due to in-stent thrombosis or covered vessel occlusion during long-term follow-up are a concern. Therapeutic ICA occlusion after test occlusion was historically the standard treatment for this disease. Bechan et al. reported in 2015 that this strategy is safe, effective, and still the preferred treatment because most aneurysms shrunk, and most cranial nerve dysfunctions were cured or improved without antiplatelet therapy. ${ }^{31)}$ Several ongoing randomized trials of FDs are under way in North America and Europe $^{32)}$ and will help to more rigorously determine the efficacy of this new technology in the near future.

\section{Carotid artery stenting}

Recently, the Asymptomatic Carotid Trial (ACT) I, involving asymptomatic patients with severe carotid stenosis who were not at high risk for carotid endarterectomy (CEA), proved that carotid artery stenting (CAS) was not inferior to CEA with regard to the primary composite end point (event rate $3.8 \%$ and $3.4 \%$, respectively; $P=0.01$ for non-inferiority). ${ }^{7}$ However, CAS remains an alternative treatment for CEA in Europe and the United States because of the

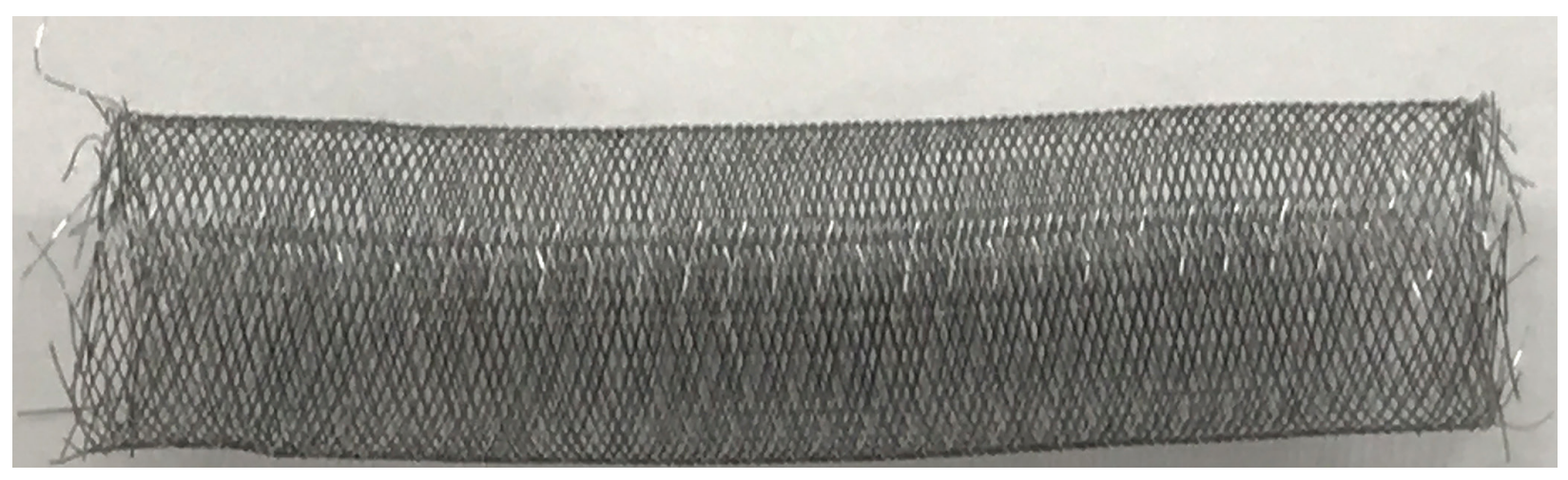

Fig. 2 Pipeline Embolic Device (Medtronic, Irvine, CA, USA). Flow-diverter stent for cerebral aneurysms. 
negative results of randomized trials of symptomatic patients. ${ }^{4-6,33)}$ In Japan, CAS seems to be the preferred treatment because of its favorable results. The Japanese Registry of Neuroendovascular Therapy (JR-NET) 1 and 2, which are retrospective nationwide multicenter surveillances, reported a low clinically significant complication rate $(3.2 \%)$ among 7134 procedures (1943 for JR-NET1 and 5191 for JR-NET2). ${ }^{34)}$ Multivariate logistic analysis revealed that age (OR 1.04 per year; 95\% 1.02-1.07; $P=0.0004)$, symptomatic lesion (OR 1.87; 95\% CI, 1.31-2.71; $P=0.0004$ ), and the use of a closed-cell type stent (OR 0.58; 95\% CI $0.32-1.00 ; P=0.05$ ) were independently associated with clinically significant complications.

CAS with embolic protection is effective in obtaining favorable outcomes. However, difficult vascular anatomy such as type III or diseased aortic arch, carotid tortuosity, difficult peripheral access, and difficult distal landing may lead to complications. Fanous et al. developed a scoring system using demographics and vascular anatomy that predicts complications, ${ }^{35)}$ whereby patients with a high score should avoid CAS. Furthermore, improved imaging techniques such as CT, magnetic resonance imaging, and ultrasonography have enabled us to understand not only the degree of carotid artery stenosis but also the vulnerability of the plaque, which stratify the risk of patients or treatments. ${ }^{36)}$

With recently developed devices and imaging technology, CAS has become a safer revascularization procedure. However, the best available medical treatment, including lifestyle modification, blood pressure and diabetes control, antiplatelet agents, and lipid-lowering therapy is the cornerstone of the management of patients with either asymptomatic or symptomatic carotid artery stenosis. ${ }^{37)}$ Stroke rates for asymptomatic carotid patients with best medical treatment alone have decreased to approximately $0.5 \%$ per year. ${ }^{38)}$

\section{Endovascular treatment for brain arteriovenous malformations (BAVM)}

Liquid embolic materials are mainly used for embolization of BAVM. Onyx (Medtronic, Irvine, CA, USA) is the latest agent in addition to n-butyl cyanoacrylate (NBCA). A meta-analysis of Onyx and NBCA including 103 studies comprising 3593 patients was performed. ${ }^{39}$ ) Complete obliteration of AVM was seen in $13.7 \%$ in the NBCA group and $24 \%$ in the Onyx group (OR 1.9). However, neurological outcomes for NBCA and Onyx were only $5.2 \%$ and $6.8 \%$, respectively (OR 1.4; $p=0.56$ ). Onyx appeared to increase the cure rate of AVMs but with a possible increase in permanent neurological deficits and mortality.
A randomized trial of unruptured brain arteriovenous malformations (ARUBA) is a multicenter, non-blinded, randomized trial comparing medical management alone and medical management with interventional therapy in patients with unruptured BAVM. Randomization was stopped in mid-study because of the superiority of the medical management group, and the authors concluded that the risk of death or stroke was significantly lower in the medical management group than in the interventional therapy group (hazard ratio $0.27,95 \%$ CI 0.14-0.54). ${ }^{40)}$ The ARUBA trial was followed by many reports delivering favorable results of interventional therapy, especially surgical removal for ARUBA eligible patients, which showed a high cure rate and excellent functional outcomes. ${ }^{41-47)}$

The ARUBA trial includes some limitations such as a low randomization rate, bias toward non-surgical therapies, shortage of surgical expertise, lower rate of complete AVM obliteration, higher rate of delayed hemorrhage, and short study duration. Its design and conclusions remain controversial. However, the annual bleeding rate $(2.2 \%)$ of the medical management group obtained by prospective study is worthy of consideration when deciding upon treatment strategy.

BAVM was believed previously to be a congenital lesion attributable to developmental failure of embryos. Recently, reports have appeared of de novo BAVM in disease-free patients with no previous diagnosis, ${ }^{48,49)}$ with hereditary hemorrhagic telangiectasia, ${ }^{50)}$ after radiation therapy, ${ }^{511}$ and after implantation of genetically modified allogeneic mesenchymal stem cells in the brain. ${ }^{52)}$ The fact that the average age at the initial diagnosis of BAVM is about 30-40 years old contradicts its congenital nature ${ }^{53)}$ or presence at birth, in contrast to vein of Galen aneurysmal malformations. ${ }^{54)}$ Komiyama mentioned on reviewing their pathogenesis that BAVMs are "dynamic" lesions that can grow, remodel, and regress in addition to rupture. ${ }^{55)}$

\section{Conclusion}

Neuro-endovascular treatment makes use of new technology to expand indications and improve results, with further development expected. The impact of mechanical thrombectomy is potentially formidable. However, as new treatments with new devices currently lack long-term results, detailed observational study of long-term follow-up data and scientific evaluation of new treatments are warranted.

\section{Conflicts of Interest Disclosure}

YM received honoraria from Medtronic Japan and Stryker Japan for lecture fees. EI, TY, and AM 
have no conflicts of interest. The authors registered online Self-reported COI Disclosure Statement Forms through the website for Japan Neurosurgical Society members.

\section{References}

1) Molyneux A, Kerr R, Stratton I, Sandercock P, Clarke M, Shrimpton J, Holman R; International Subarachnoid Aneurysm Trial (ISAT) Collaborative Group: International Subarachnoid Aneurysm Trial (ISAT) of neurosurgical clipping versus endovascular coiling in 2143 patients with ruptured intracranial aneurysms: a randomised trial. Lancet 360: 1267-1274, 2002

2) McDougall CG, Spetzler RF, Zabramski JM, Partovi S, Hills NK, Nakaji P, Albuquerque FC: The barrow ruptured aneurysm trial. J Neurosurg 116: 135-144, 2012

3) Brott TG, Hobson RW, Howard G, Roubin GS, Clark WM, Brooks W, Mackey A, Hill MD, Leimgruber PP, Sheffet AJ, Howard VJ, Moore WS, Voeks JH, Hopkins LN, Cutlip DE, Cohen DJ, Popma JJ, Ferguson RD, Cohen SN, Blackshear JL, Silver FL, Mohr JP, Lal BK, Meschia JF; CREST Investigators: Stenting versus endarterectomy for treatment of carotid-artery stenosis. N Engl J Med 363: 11-23, 2010

4) Ederle J, Dobson J, Featherstone RL, Bonati LH, van der Worp HB, de Borst GJ, Lo TH, Gaines P, Dorman PJ, Macdonald S, Lyrer PA, Hendriks JM, McCollum C, Nederkoorn PJ, Brown MM; International Carotid Stenting Study investigators: Carotid artery stenting compared with endarterectomy in patients with symptomatic carotid stenosis (International Carotid Stenting Study): an interim analysis of a randomised controlled trial. Lancet 375: 985-997, 2010

5) Ringleb PA, Allenberg J, Brückmann H, Eckstein HH, Fraedrich G, Hartmann M, Hennerici M, Jansen O, Klein G, Kunze A, Marx P, Niederkorn K, Schmiedt W, Solymosi L, Stingele R, Zeumer H, Hacke W: 30 day results from the SPACE trial of stent-protected angioplasty versus carotid endarterectomy in symptomatic patients: a randomised non-inferiority trial. Lancet 368: 1239-1247, 2006

6) Mas JL, Chatellier G, Beyssen B, Branchereau A, Moulin T, Becquemin JP, Larrue V, Lièvre M, Leys D, Bonneville JF, Watelet J, Pruvo JP, Albucher JF, Viguier A, Piquet P, Garnier P, Viader F, Touzé E, Giroud M, Hosseini H, Pillet JC, Favrole P, Neau JP, Ducrocq X; EVA-3S Investigators: Endarterectomy versus stenting in patients with symptomatic severe carotid stenosis. $N$ Engl J Med 355: 1660-1671, 2006

7) Rosenfield K, Matsumura JS, Chaturvedi S, Riles T, Ansel GM, Metzger DC, Wechsler L, Jaff MR, Gray W; ACT I Investigators: Randomized trial of stent versus surgery for asymptomatic carotid stenosis. N Engl J Med 374: 1011-1020, 2016

8) Berkhemer OA, Fransen PS, Beumer D, van den Berg LA, Lingsma HF, Yoo AJ, Schonewille WJ, Vos JA,
Nederkoorn PJ, Wermer MJ, van Walderveen MA, Staals J, Hofmeijer J, van Oostayen JA, Lycklama à Nijeholt GJ, Boiten J, Brouwer PA, Emmer BJ, de Bruijn SF, van Dijk LC, Kappelle LJ, Lo RH, van Dijk EJ, de Vries J, de Kort PL, van Rooij WJ, van den Berg JS, van Hasselt BA, Aerden LA, Dallinga RJ, Visser MC, Bot JC, Vroomen PC, Eshghi O, Schreuder TH, Heijboer RJ, Keizer K, Tielbeek AV, den Hertog HM, Gerrits DG, van den Berg-Vos RM, Karas GB, Steyerberg EW, Flach HZ, Marquering HA, Sprengers ME, Jenniskens SF, Beenen LF, van den Berg R, Koudstaal PJ, van Zwam WH, Roos YB, van der Lugt $A$, van Oostenbrugge RJ, Majoie CB, Dippel DW; MR CLEAN Investigators: A randomized trial of intraarterial treatment for acute ischemic stroke. N Engl J Med 372: 11-20, 2015

9) Goyal M, Demchuk AM, Menon BK, Eesa M, Rempel JL, Thornton J, Roy D, Jovin TG, Willinsky RA, Sapkota BL, Dowlatshahi D, Frei DF, Kamal NR, Montanera WJ, Poppe AY, Ryckborst KJ, Silver FL, Shuaib A, Tampieri D, Williams D, Bang OY, Baxter BW, Burns PA, Choe H, Heo JH, Holmstedt CA, Jankowitz B, Kelly M, Linares G, Mandzia JL, Shankar J, Sohn SI, Swartz RH, Barber PA, Coutts SB, Smith EE, Morrish WF, Weill A, Subramaniam S, Mitha AP, Wong JH, Lowerison MW, Sajobi TT, Hill MD; ESCAPE Trial Investigators: Randomized assessment of rapid endovascular treatment of ischemic stroke. N Engl J Med 372: 1019-1030, 2015

10) Campbell BC, Mitchell PJ, Kleinig TJ, Dewey HM, Churilov L, Yassi N, Yan B, Dowling RJ, Parsons MW, Oxley TJ, Wu TY, Brooks M, Simpson MA, Miteff F, Levi CR, Krause M, Harrington TJ, Faulder KC, Steinfort BS, Priglinger M, Ang T, Scroop R, Barber PA, McGuinness B, Wijeratne T, Phan TG, Chong W, Chandra RV, Bladin CF, Badve M, Rice H, de Villiers L, Ma H, Desmond PM, Donnan GA, Davis SM; EXTEND IA Investigators: Endovascular therapy for ischemic stroke with perfusion-imaging selection. N Engl J Med 372: 1009-1018, 2015

11) Saver JL, Goyal M, Bonafe A, Diener HC, Levy EI, Pereira VM, Albers GW, Cognard C, Cohen DJ, Hacke W, Jansen O, Jovin TG, Mattle HP, Nogueira RG, Siddiqui AH, Yavagal DR, Baxter BW, Devlin TG, Lopes DK, Reddy VK, du Mesnil de Rochemont R, Singer OC, Jahan R; SWIFT PRIME Investigators: Stent-retriever thrombectomy after intravenous t-PA vs. t-PA alone in stroke. $N$ Engl J Med 372: 2285-2295, 2015

12) Jovin TG, Chamorro A, Cobo E, de Miquel MA, Molina CA, Rovira A, San Román L, Serena J, Abilleira S, Ribó M, Millán M, Urra X, Cardona P, López-Cancio E, Tomasello A, Castaño C, Blasco J, Aja L, Dorado L, Quesada H, Rubiera M, HernandezPérez M, Goyal M, Demchuk AM, von Kummer R, Gallofré M, Dávalos A; REVASCAT Trial Investigators: Thrombectomy within 8 hours after symptom onset in ischemic stroke. $N$ Engl J Med 372: 2296-2306, 2015 
13) del Zoppo GJ, Ferbert A, Otis S, Brückmann H, Hacke W, Zyroff J, Harker LA, Zeumer H: Local intra-arterial fibrinolytic therapy in acute carotid territory stroke. A pilot study. Stroke 19: 307-313, 1988

14) Jayaraman MV, Hussain MS, Abruzzo T, Albani B, Albuquerque FC, Alexander MJ, Ansari SA, Arthur AS, Baxter B, Bulsara KR, Chen M, Delgado Almandoz JE, Fraser JF, Delgado-Almandoz JA, Heck DV, Hetts SW, Kelly M, Lee SK, Leslie-Mawzi T, McTaggart RA, Meyers PM, Prestigiacomo C, Pride GL, Patsalides A, Starke RM, Tarr RW, Frei D, Rasmussen P; Standards and Guidelines Committee of the Society of NeuroInterventional Surgery: Embolectomy for stroke with emergent large vessel occlusion (ELVO): report of the Standards and Guidelines Committee of the Society of NeuroInterventional Surgery. J Neurointerv Surg 7: 316-321, 2015

15) Powers WJ, Derdeyn CP, Biller J, Coffey CS, Hoh BL, Jauch EC, Johnston KC, Johnston SC, Khalessi AA, Kidwell CS, Meschia JF, Ovbiagele B, Yavagal DR; American Heart Association Stroke Council: 2015 American Heart Association/American Stroke Association focused update of the 2013 guidelines for the early management of patients with acute ischemic stroke regarding endovascular treatment: a guideline for healthcare professionals from the American Heart Association/American Stroke Association. Stroke 46: 3020-3035, 2015

16) Goyal M, Menon BK, van Zwam WH, Dippel DWJ, Mitchell PJ, Demchuk AM, Dávalos A, Majoie CBLM, van der Lugt A, de Miquel MA, Donnan GA, Roos YBWEM, Bonafe A, Jahan R, Diener H-C, van den Berg LA, Levy EI, Berkhemer OA, Pereira VM, Rempel J, Millán M, Davis SM, Roy D, Thornton J, Román LS, Ribó M, Beumer D, Stouch B, Brown S, Campbell BC, van Oostenbrugge RJ, Saver JL, Hill MD, Jovin TG; HERMES collaborators: Endovascular thrombectomy after large-vessel ischaemic stroke: a meta-analysis of individual patient data from five randomised trials. Lancet 387: 1723-1731, 2016

17) English JD, Yavagal DR, Gupta R, Janardhan V, Zaidat OO, Xavier AR, Nogueira RG, Kirmani JF, Jovin TG: Mechanical thrombectomy-ready comprehensive stroke center requirements and endovascular stroke systems of care: recommendations from the Endovascular Stroke Standards Committee of the Society of Vascular and Interventional Neurology (SVIN). Interv Neurol 4: 138-150, 2016

18) Campbell BC, Hill MD, Rubiera M, Menon BK, Demchuk A, Donnan GA, Roy D, Thornton J, Dorado L, Bonafe A, Levy EI, Diener HC, Hernández-Pérez M, Pereira VM, Blasco J, Quesada H, Rempel J, Jahan R, Davis SM, Stouch BC, Mitchell PJ, Jovin TG, Saver JL, Goyal M: Safety and efficacy of Solitaire stent thrombectomy: individual patient data meta-analysis of randomized trials. Stroke 47: 798-806, 2016

19) Fransen PS, Berkhemer OA, Lingsma HF, Beumer D, van den Berg LA, Yoo AJ, Schonewille WJ, Vos JA, Nederkoorn PJ, Wermer MJ, van Walderveen MA, Staals J, Hofmeijer J, van Oostayen JA, Lycklama À,
Nijeholt GJ, Boiten J, Brouwer PA, Emmer BJ, de Bruijn SF, van Dijk LC, Kappelle LJ, Lo RH, van Dijk EJ, de Vries J, de Kort PL, van den Berg JS, van Hasselt BA, Aerden LA, Dallinga RJ, Visser MC, Bot JC, Vroomen PC, Eshghi O, Schreuder TH, Heijboer RJ, Keizer K, Tielbeek AV, den Hertog HM, Gerrits DG, van den Berg-Vos RM, Karas GB, Steyerberg EW, Flach HZ, Marquering HA, Sprengers ME, Jenniskens SF, Beenen LF, van den Berg R, Koudstaal PJ, van Zwam WH, Roos YB, van Oostenbrugge RJ, Majoie CB, van der Lugt A, Dippel DW; Multicenter Randomized Clinical Trial of Endovascular Treatment of Acute Ischemic Stroke in the Netherlands Investigators: Time to reperfusion and treatment effect for acute ischemic stroke: a randomized clinical trial. JAMA Neurol 73: 190-196, 2016

20) Menon BK, Sajobi TT, Zhang Y, Rempel JL, Shuaib A, Thornton J, Williams D, Roy D, Poppe AY, Jovin TG, Sapkota B, Baxter BW, Krings T, Silver FL, Frei DF, Fanale C, Tampieri D, Teitelbaum J, Lum C, Dowlatshahi D, Eesa M, Lowerison MW, Kamal NR, Demchuk AM, Hill MD, Goyal M: Analysis of workflow and time to treatment on thrombectomy outcome in the Endovascular Treatment for Small Core and Proximal Occlusion Ischemic Stroke (ESCAPE) randomized, controlled trial. Circulation 133: 2279-2286, 2016

21) Ribo M, Molina CA, Cobo E, Cerdà N, Tomasello A, Quesada H, De Miquel MA, Millan M, Castaño C, Urra X, Sanroman L, Dàvalos A, Jovin T; REVASCAT Trial Investigators: Association between time to reperfusion and outcome is primarily driven by the time from imaging to reperfusion. Stroke 47: 999-1004, 2016

22) Lylyk P, Miranda C, Ceratto R, Ferrario A, Scrivano E, Luna HR, Berez AL, Tran Q, Nelson PK, Fiorella D: Curative endovascular reconstruction of cerebral aneurysms with the pipeline embolization device: the Buenos Aires experience. Neurosurgery 64, 632-642; discussion 642-643, 2009

23) Szikora I, Berentei Z, Kulcsar Z, Marosfoi M, Vajda ZS, Lee W, Berez A, Nelson PK. Treatment of intracranial aneurysms by functional reconstruction of the parent artery: the Budapest experience with the pipeline embolization device: AJNR Am J Neuroradiol 31: 1139-1147, 2010

24) Nelson PK, Lylyk P, Szikora I, Wetzel SG, Wanke I, Fiorella D: The pipeline embolization device for the intracranial treatment of aneurysms trial. AJNR Am J Neuroradiol 32: 34-40, 2011

25) Becske T, Kallmes DF, Saatci I, McDougall CG, Szikora I, Lanzino G, Moran CJ, Woo HH, Lopes DK, Berez AL, Cher DJ, Siddiqui AH, Levy EI, Albuquerque FC, Fiorella DJ, Berentei Z, Marosfoi M, Cekirge SH, Nelson PK: Pipeline for uncoilable or failed aneurysms: results from a multicenter clinical trial. Radiology 267: 858-868, 2013

26) Becske T, Potts MB, Shapiro M, Kallmes DF, Brinjikji W, Saatci I, McDougall CG, Szikora I, Lanzino G, Moran CJ, Woo HH, Lopes DK, Berez AL, Cher 
DJ, Siddiqui AH, Levy EI, Albuquerque FC, Fiorella DJ, Berentei Z, Marosfoi M, Cekirge SH, Nelson PK: Pipeline for uncoilable or failed aneurysms: 3-year follow-up results. J Neurosurg 1-8, 2016

27) Kallmes DF, Hanel R, Lopes D, Boccardi E, Bonafé A, Cekirge S, Fiorella D, Jabbour P, Levy E, McDougall C, Siddiqui A, Szikora I, Woo H, Albuquerque F, Bozorgchami H, Dashti SR, Delgado Almandoz JE, Kelly ME, Turner R, Woodward BK, Brinjikji W, Lanzino G, Lylyk P: International retrospective study of the pipeline embolization device: a multicenter aneurysm treatment study. AJNR Am J Neuroradiol 36: 108-115, 2015

28) Brinjikji W, Lanzino G, Cloft HJ, Siddiqui AH, Kallmes DF: Risk factors for hemorrhagic complications following pipeline embolization device treatment of intracranial aneurysms: results from the International Retrospective Study of the Pipeline Embolization Device. AJNR Am J Neuroradiol 36: 2308-2313, 2015

29) Sahlein DH, Fouladvand M, Becske T, Saatci I, McDougall CG, Szikora I, Lanzino G, Moran CJ, Woo HH, Lopes DK, Berez AL, Cher DJ, Siddiqui AH, Levy EI, Albuquerque FC, Fiorella DJ, Berentei Z, Marosfoi M, Cekirge SH, Kallmes DF, Nelson PK: Neuroophthalmological outcomes associated with use of the Pipeline Embolization Device: analysis of the PUFS trial results. J Neurosurg 123: 897-905, 2015

30) Neki H, Caroff J, Jittapiromsak P, Benachour N, Mihalea C, Ikka L, Moret J, Spelle L: Patency of the anterior choroidal artery covered with a flowdiverter stent. J Neurosurg 123: 1540-1545, 2015

31) Bechan RS, Majoie CB, Sprengers ME, Peluso JP, Sluzewski M, van Rooij WJ: Therapeutic internal carotid artery occlusion for large and giant aneurysms: a single center cohort of 146 patients. Am J Neuroradiol 37: 125-129, 2016

32) Walcott BP, Stapleton CJ, Choudhri O, Patel AB: Flow diversion for the treatment of intracranial aneurysms. JAMA Neurol 73: 1002-1008, 2016

33) Dumont TM, Rughani AI: National trends in carotid artery revascularization surgery. J Neurosurg 116: 1251-1257, 2012

34) Egashira Y, Yoshimura S, Sakai N, Enomoto Y: Real-world Experience of Carotid Artery Stentingin Japan: Analysis of 7,134 cases from JR-NET1 and 2 nationwide retrospective multi-center registries. Neurol Med Chir(Tokyo) 54 Suppl 2: 32-39, 2014

35) Fanous AA, Natarajan SK, Jowdy PK, Dumont TM, Mokin M, Yu J, Goldstein A, Wach MM, Budny JL, Hopkins LN, Snyder KV, Siddiqui AH, Levy EI: High-risk factors in symptomatic patients undergoing carotid artery stenting with distal protection: Buffalo Risk Assessment Scale (BRASS). Neurosurgery 77: 531-542; discussion 542-543, 2015

36) Brinjikji W, Huston J, Rabinstein AA, Kim GM, Lerman A, Lanzino G: Contemporary carotid imaging: from degree of stenosis to plaque vulnerability. J Neurosurg 124: 27-42, 2016
37) Paraskevas KI, Mikhailidis DP, Veith FJ, Spence JD: Definition of best medical treatment in asymptomatic and symptomatic carotid artery stenosis. Angiology 67: 411-419, 2016

38) Spence JD: Management of asymptomatic carotid stenosis. Neurol Clin 33: 443-457, 2015

39) Elsenousi A, Aletich VA, Alaraj A: Neurological outcomes and cure rates of embolization of brain arteriovenous malformations with n-butyl cyanoacrylate or Onyx: a meta-analysis. J Neurointerv Surg 8: 265-272, 2016

40) Mohr JP, Parides MK, Stapf C, Moquete E, Moy CS, Overbey JR, Al-Shahi Salman R, Vicaut E, Young WL, Houdart E, Cordonnier C, Stefani MA, Hartmann A, von Kummer R, Biondi A, Berkefeld J, Klijn CJ, Harkness K, Libman R, Barreau X, Moskowitz AJ: Medical management with or without interventional therapy for unruptured brain arteriovenous malformations (ARUBA): a multicentre, non-blinded, randomised trial. Lancet 383: 614-621, 2014

41) Rutledge WC, Abla AA, Nelson J, Halbach VV, Kim H, Lawton MT: Treatment and outcomes of ARUBA-eligible patients with unruptured brain arteriovenous malformations at a single institution. Neurosurg Focus 37: E8, 2014

42) Bervini D, Morgan MK, Ritson EA, Heller G: Surgery for unruptured arteriovenous malformations of the brain is better than conservative management for selected cases: a prospective cohort study. J Neurosurg 121: 878-890, 2014

43) Potts MB, Lau D, Abla AA, Kim H, Young WL, Lawton MT; ; UCSF Brain AVM Study Project: Current surgical results with low-grade brain arteriovenous malformations. J Neurosurg 122: 912-920, 2015

44) Nerva JD, Mantovani A, Barber J, Kim LJ, Rockhill JK, Hallam DK, Ghodke BV, Sekhar LN: Treatment outcomes of unruptured arteriovenous malformations with a subgroup analysis of ARUBA (A Randomized Trial of Unruptured Brain Arteriovenous Malformations)-eligible patients. Neurosurgery 76: 563-570; discussion 570; quiz 570, 2015

45) Schramm J, Schaller K, Esche J, Boström A: Microsurgery for cerebral arteriovenous malformations: subgroup outcomes in a consecutive series of 288 cases. J Neurosurg 1-8, 2016

46) Ding D, Starke RM, Kano H, Mathieu D, Huang P, Kondziolka D, Feliciano C, Rodriguez-Mercado R, Almodovar L, Grills IS, Silva D, Abbassy M, Missios S, Barnett GH, Lunsford LD, Sheehan JP: Radiosurgery for cerebral arteriovenous malformations in A Randomized Trial of Unruptured Brain Arteriovenous Malformations (ARUBA)-Eligible patients: A multicenter study. Stroke 47: 342-349, 2016

47) Moon K, Levitt MR, Almefty RO, Nakaji P, Albuquerque FC, Zabramski JM, Wanebo JE, McDougall CG, Spetzler RF: Safety and efficacy of surgical resection of unruptured low-grade arteriovenous malformations 
from the modern decade. Neurosurgery 77: 948-952; discussion 952-953, 2015

48) Jeffree RL, Stoodley MA: Postnatal development of arteriovenous malformations. Pediatr Neurosurg 45: 296-304, 2009

49) Gonzalez LF, Bristol RE, Porter RW, Spetzler RF: De novo presentation of an arteriovenous malformation. Case report and review of the literature. J Neurosurg 102: 726-729, 2005

50) Shimoda Y, Osanai T, Nakayama N, Ushikoshi S, Hokari M, Shichinohe H, Abumiya T, Kazumata K, Houkin K: De novo arteriovenous malformation in a patient with hereditary hemorrhagic telangiectasia. J Neurosurg Pediatr 17: 330-335, 2016

51) Koch MJ, Agarwalla PK, Stapleton CJ, Ogilvy CS, Loeffler JS: De novo development of a cerebral arteriovenous malformation following radiation therapy. Case report and an update to classical arteriovenous malformation nomenclature. J Clin Neurosci 28: 162-167, 2016

52) Nakamura M, Samii A, Lang JM, Götz F, Samii M, Krauss JK: De novo arteriovenous malformation growth secondary to implantation of genetically modified allogeneic mesenchymal stem cells in the brain. Neurosurgery 78: E596-E600, 2016

53) Stapf C, Mast H, Sciacca RR, Berenstein A, Nelson PK, Gobin YP, Pile-Spellman J, Mohr JP; New York Islands AVM Study Collaborators: design, study progress, and initial results. Stroke 34: e29-e33, 2003

54) Komiyama M, Nakajima H, Nishikawa M, Kitano $\mathrm{S}$, Sakamoto $\mathrm{H}$ : Interventional neuroangiography in neonates. Intervent Neuroradiol 5 Suppl 1, 127-132, 1999

55) Komiyama M: Pathogenesis of brain arteriovenous malformations. Neurol Med Chir (Tokyo) 56: 317-325, 2016

Address reprint requests to: Yuji Matsumaru, MD, PhD, Division for Stoke, Department of Neurosurgery, Faculty of Medicine, University of Tsukuba, 1-1-1, Tennodai, Tsukuba, Ibaraki 305-8575, Japan. e-mail: yujimatsumaru@md.tsukuba.ac.jp 